\title{
In vitro anti-leishmanial and anti-fungal effects of new Sb' carboxylates
}

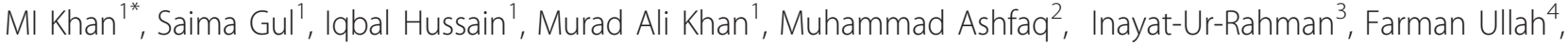 \\ Gulrez Fatima Durrani ${ }^{5}$, Imam Bakhsh Baloch ${ }^{5}$ and Rubina Naz ${ }^{5}$
}

\begin{abstract}
Ring opening of phthalic anhydride has been carried out in acetic acid with glycine, $\beta$-alanine, L-phenylalanine, and 4-aminobenzoic acid to yield, respectively, 2-\{[(carboxymethyl)amino]carbonyl\}benzoic acid (I), 2-\{[(2carboxyethyl)amino]carbonyl\}benzoic acid (II), 2-\{[(1-carboxy-2-phenylethyl)amino]carbonyl\}benzoic acid (III), and 2[(4-carboxyanilino)carbonyl] benzoic acid (IV). Compounds I-IV have been employed as ligands for Sb(III) center (complexes V-VIII) in aqueous medium. FTIR and ${ }^{1} \mathrm{H}$ NMR spectra proved the deprotonation of carboxylic protons and coordination of imine group and thereby tridentate behaviour of the ligands as chelates. Elemental, MS, and TGA analytic data confirmed the structural hypothesis based on spectroscopic results. All the compounds have been assayed in vitro for anti-leishmanial and anti-fungal activities against five leishmanial strains L. major (JISH118), L. major (MHOM/PK/88/DESTO), L. tropica (K27), L. infantum (LEM3437), L. mex mex (LV4), and L. donovani (H43); and Aspergillus Flavus, Aspergillus Fumigants, Aspergillus Niger, and Fusarium Solani. Compound VII exhibited good antileishmanial as well as anti-fungal impacts comparable to reference drugs.
\end{abstract}

Keywords: antimony(III) carboxylates, anti-leishmanial, anti-fungal

\section{Background}

Trivalent antimony reagents are extensively consumed in industrial processes, e.g., in catalysis for the synthesis of polymers akin ethyleneterephthalate, with different brand names like Dacron ${ }^{\circledR}$ and Mylar ${ }^{\circledR}$. Similarly, antimony alkoxides have also been employed as precursors for the deposition of thin films of $\mathrm{Sb}_{2} \mathrm{O}_{3}$ and $\mathrm{Sb}_{6} \mathrm{O}_{13}$ [1-4]. The literature also revealed use of trivalent antimony compounds in fluorine chemistry and their suitability as solid electrolytes, piezoelectrics, and ferroelectrics $[5,6]$. On the other hand, the use of triand pentavalent antimony containing compounds as drugs for the treatment of leishmaniasis span more than 50 years; but little is known about the actual mechanisms of antimony toxicity and drug resistance $[7,8]$. Carboxylic group-containing compounds are versatile ligands to act as unidentate, bidentate, or bridging ligands; moreover, these also act as a spacer between $\mathrm{Sb}$ and other moieties [9-13]. All these facts prompted us

\footnotetext{
* Correspondence: gorikhan@kohat.edu.pk

'Department of Chemistry, Kohat University of Science \& Technology, Kohat 26000, Khyber Pakhtunkhwa, Pakistan

Full list of author information is available at the end of the article
}

to investigate the chemistry as well and biocidal effects of antimony ${ }^{\text {III }}$ complexes formed with ligands containing two carboxylic groups.

\section{Experimental}

As received grade chemicals used during this study were procured from Sigma; the solvents were dried as reported [14]. C, $\mathrm{H}$, and $\mathrm{N}$ analyses were carried out on a Yanaco high-speed $\mathrm{CHN}$ analyzer; antipyrene was used as a reference, while antimony was estimated according to the reported procedure [15]; melting points were recorded on Gallenkmp capillary melting point apparatus and are uncorrected. FTIR spectra of all the compounds were taken on Bruker FTIR spectrophotometer TENSOR27 using OPUS software in the range of $5000-400 \mathrm{~cm}^{-1}$ (ZnSe). ${ }^{1} \mathrm{H}$ and ${ }^{13} \mathrm{C}$ NMR spectra in DMSO were recorded on a multinuclear Avance 300 and $75 \mathrm{MHz}$ FT NMR spectrometer operating at room temperature, i.e., $25 \mathrm{C}$. Thermoanalytical measurements were carried out using a Perkin Elmer Thermogravimetric/differential thermal analyzer (YRIS Diamond TGDTA High Temp. Vacu.) consuming variable heating rates between $0.5^{\circ} \mathrm{C} / \mathrm{min}$ and $50^{\circ} \mathrm{C} / \mathrm{min}$. HR FAB-MS

\section{SpringerOpen ${ }^{\top}$}


spectra were obtained from a double-focusing mass spectrometer Finnigan (MAT 112).

\section{Synthesis of ligands}

Phthalic anhydride (5 g, $33.77 \mathrm{mM}$ ) was dissolved in acetic acid $(100 \mathrm{~mL})$, and a cold solution of amino acid (33.77 mM, i.e. $2.53 \mathrm{~g}, 3 \mathrm{~g}, 5.58 \mathrm{~g}$, and $4.63 \mathrm{~g}$ of glycine, $\beta$-alanine, L-phenylalanine, and 4-aminobenzoic acid, respectively) in acetic acid ( $75 \mathrm{~mL}$ ) was added to it. This mixture was stirred at room temperature for 3 hours resulting in white precipitate. The white precipitate was washed several times with cold water and recrystallized from water.

\section{Synthesis of I}

Yield: $72 \% . \mathrm{C}_{10} \mathrm{H}_{9} \mathrm{NO}_{5}$ : Calcd. (\%): C 53.82, $\mathrm{H} 4.06$, and $\mathrm{N}$ 6.28; Found (\%): C 53.27, H 3.86, N 6.01; FAB-MS $(m / z) 224(\mathrm{M}+1)$; IR $v 3293(\mathrm{~N}-\mathrm{H}), 1684(\mathrm{C}-\mathrm{N}), 1592$ $\left(\mathrm{CO}_{2}\right)_{\mathrm{as}}$, and $1353\left(\mathrm{CO}_{2}\right)_{\mathrm{s}}, \Delta v\left(\mathrm{CO}_{2}\right): 239 \mathrm{~cm}^{-1} .{ }^{1} \mathrm{H}$ NMR (DMSO-d6, $300 \mathrm{MHz}) 12.8$ (s, $\mathrm{COOH}), 12.1$ (s, $\mathrm{COOH}$ ), $8.31(\mathrm{~s}, \mathrm{NH}), 7.02-7.61(\mathrm{Ar})$, and $3.62\left(\mathrm{~s}, \mathrm{CH}_{2}\right) .{ }^{13} \mathrm{C}$ NMR (DMSO-d6, $75 \mathrm{MHz}) 174.7$ (COOH), 170.2 $(\mathrm{CONH}), 168.9(\mathrm{COOH}), 107-138(\mathrm{Ar})$, and $44.6\left(\mathrm{CH}_{2}\right)$.

\section{Synthesis of II}

Yield: $67 \% . \mathrm{C}_{11} \mathrm{H}_{11} \mathrm{NO}_{5}$ : Calcd. (\%): C 55.70, H 4.67, N 5.90; Found (\%): C 55.24, H 4.03, N 5.42. FAB-MS $(\mathrm{m} / \mathrm{z})$ $238(\mathrm{M}+1)$. IR $v 3372(\mathrm{~N}-\mathrm{H}), 1670(\mathrm{C}-\mathrm{N}), 1581\left(\mathrm{CO}_{2}\right)$ as, $1345\left(\mathrm{CO}_{2}\right)_{\mathrm{s}}, \Delta v\left(\mathrm{CO}_{2}\right): 236 \mathrm{~cm}^{-1} .{ }^{1} \mathrm{H}$ NMR (DMSOd6, $300 \mathrm{MHz}) 12.7$ (s, $\mathrm{COOH}), 12.5$ (s, $\mathrm{COOH}), 8.39$ (s, $\mathrm{NH})$, 7.07-7.59, (m, Ar) $3.51\left(\mathrm{t}, \mathrm{CH}_{2} \mathrm{~J}: 3.42\right), 2.33(\mathrm{t}$, $\mathrm{CH}_{2}$ J: 4.1). ${ }^{13} \mathrm{C}$ NMR (DMSO-d6, $\left.75 \mathrm{MHz}\right) 173.2$ $(\mathrm{COOH}), 168.8(\mathrm{COOH}), 142.4(\mathrm{CONH}), 109-140(\mathrm{Ar})$, 40.4 $\left(\mathrm{CH}_{2}\right), 35.2\left(\mathrm{CH}_{2}\right)$.

\section{Synthesis of III}

Yield: $80 \%$. $\mathrm{C}_{17} \mathrm{H}_{15} \mathrm{NO}_{5}$ : Calcd. (\%): C 65.17, H 4.83, N 4.47; Found (\%): C 64.86, H 4.32, N 4.11. FAB-MS $(\mathrm{m} / \mathrm{z})$ $314(\mathrm{M}+1) . \mathrm{IR} v 3380(\mathrm{~N}-\mathrm{H}), 1686(\mathrm{C}-\mathrm{N}), 1577\left(\mathrm{CO}_{2}\right)$ as, $1361\left(\mathrm{CO}_{2}\right)_{\mathrm{s}}, \Delta v\left(\mathrm{CO}_{2}\right): 216 \mathrm{~cm}^{-1} .{ }^{1} \mathrm{H}$ NMR (DMSOd6, $300 \mathrm{MHz}) 12.6(\mathrm{~s}, \mathrm{COOH}), 12.2(\mathrm{~s}, \mathrm{COOH}), 8.43(\mathrm{~s}$, $\mathrm{NH}$ ), 7.02-7.51 (m, Ar), 5.06 (q, $\mathrm{CH}, \mathrm{J}: 8.8), 3.4\left(\mathrm{~d}, \mathrm{CH}_{2}\right.$, J: 10.1). ${ }^{13} \mathrm{C}$ NMR (DMSO-d6, $\left.75 \mathrm{MHz}\right) 171.4(\mathrm{COOH})$, $170.0(\mathrm{COOH}), 144.1(\mathrm{CONH}), 111-138(\mathrm{Ar}), 61.2(\mathrm{CH})$, $36.1\left(\mathrm{CH}_{2}\right)$.

\section{Synthesis of IV}

Yield: $70 \% . \mathrm{C}_{15} \mathrm{H}_{11} \mathrm{NO}_{5}$ : Calcd. (\%): C 63.16, H 3.89, N 4.91; Found (\%): C 63.02, H 3.43, N 4.60. FAB-MS $(m / z)$ $286(\mathrm{M}+1)$. IR $v 3388(\mathrm{~N}-\mathrm{H}), 1672(\mathrm{C}-\mathrm{N}), 1566\left(\mathrm{CO}_{2}\right)_{\mathrm{as}}$, $1371\left(\mathrm{CO}_{2}\right)_{\mathrm{s}}, \Delta v\left(\mathrm{CO}_{2}\right): 195 \mathrm{~cm}^{-1} .{ }^{1} \mathrm{H}$ NMR (DMSO-d6, $300 \mathrm{MHz}) 12.3(\mathrm{~s}, \mathrm{COOH}), 11.8(\mathrm{~s}, \mathrm{COOH}), 8.52(\mathrm{~s}, \mathrm{NH})$, 7.13-8.33 (m, Ar). ${ }^{13} \mathrm{C}$ NMR (DMSO-d6, $\left.75 \mathrm{MHz}\right) 176.7$ $(\mathrm{COOH}), 165.4(\mathrm{COOH}), 148.2(\mathrm{CONH}), 120-136(\mathrm{Ar})$.

\section{Synthesis of antimony complexes}

Aqueous solution of $\mathrm{SbCl}_{3}$ was made by dissolving $0.5 \mathrm{~g}$ $(2.19 \mathrm{mM})$ in $10 \mathrm{~mL}$, and a few drops of dil. $\mathrm{HCl}$ were added; to this solution, equimolar amount of ligand 2.19 $\mathrm{mM}$, i.e. $0.48 \mathrm{~g}, 0.52 \mathrm{~g}, 0.69 \mathrm{~g}$, and $0.62 \mathrm{~g}$, respectively, for I-IV dissolved in ethanol $(20 \mathrm{~mL})$. The mixture was stirred at room temperature for $15 \mathrm{~min}$, for adjustment of $\mathrm{pH}$, and one drop of ammonia was added which resulted in the formation of a precipitate. The precipitate was filtered and washed with warm $70 \%$ ethanol and recrystallized from water.

\section{Synthesis of $\mathbf{V}$}

Yield: $58 \% . \mathrm{C}_{10} \mathrm{H}_{7} \mathrm{ClNO}_{5}$ Sb: Calcd. (\%): C 31.74, $\mathrm{H}$ 1.86, N 3.70, Sb 32.18; Found (\%): C 31.21, H 1.45, N 3.39, Sb 31.80. FAB-MS $(m / z) 377,379(\mathrm{M}+2)$. IR $v 3231(\mathrm{~N}-$ $\mathrm{H}), 1655(\mathrm{C}-\mathrm{N}), 1561\left(\mathrm{CO}_{2}\right)_{\mathrm{as}}, 1320\left(\mathrm{CO}_{2}\right)_{\mathrm{s}}, \Delta v\left(\mathrm{CO}_{2}\right)$ : 241, $450(\mathrm{~N} \rightarrow \mathrm{Sb}), 574(\mathrm{O}-\mathrm{Sb}) \mathrm{cm}^{-1} .{ }^{1} \mathrm{H}$ NMR (DMSOd6, $300 \mathrm{MHz})$ 8.24 (s, NH), 7.11-7.61 (m, Ar), 3.87 (s, $\left.\mathrm{CH}_{2}\right) \cdot{ }^{13} \mathrm{C}$ NMR (DMSO-d6, $\left.75 \mathrm{MHz}\right) 177.4(\mathrm{CONH})$, 174.7 (COO), 170.2 (COO), 107-138 (Ar), $40.2\left(\mathrm{CH}_{2}\right)$.

\section{Synthesis of $\mathrm{VI}$}

Yield: $58 \% . \mathrm{C}_{11} \mathrm{H}_{9} \mathrm{ClNO}_{5}$ Sb: Calcd. (\%): C 33.67, H 2.31, N 3.57, Sb: 31.03; Found (\%): C 33.28, H 2.08, N 3.19, Sb: 30.67. FAB-MS $(m / z)$ 391, $393(M+2)$. IR $v 3265$ $(\mathrm{N}-\mathrm{H}), 1643(\mathrm{C}-\mathrm{N}), 1551\left(\mathrm{CO}_{2}\right)_{\mathrm{as}}, 1302\left(\mathrm{CO}_{2}\right)_{\mathrm{s}}, \Delta v$ $\left(\mathrm{CO}_{2}\right): 249,442(\mathrm{~N} \rightarrow \mathrm{Sb}), 582(\mathrm{O}-\mathrm{Sb}) \mathrm{cm}^{-1} \cdot{ }^{1} \mathrm{H}$ NMR (DMSO-d6, $300 \mathrm{MHz}) 12.7$ (s, $\mathrm{COOH}), 12.5$ (s, $\mathrm{COOH}$ ), 8.39 (s, NH), 7.07-7.59, (m, Ar) 3.51 (t, $\mathrm{CH}_{2} \mathrm{~J}: 3.42$ ), $2.33\left(\mathrm{t}, \mathrm{CH}_{2} \mathrm{~J}: 4.1\right) .{ }^{13} \mathrm{C}$ NMR (DMSO-d6, $75 \mathrm{MHz}$ ) 181.4 (CONH), 170.0 (COO), 160.1 (COO), 122-142 (Ar), $33.3\left(\mathrm{CH}_{2} \mathrm{NH}\right), 27.1\left(\mathrm{CH}_{2}\right)$.

\section{Synthesis of VII}

Yield: $51 \% . \mathrm{C}_{17} \mathrm{H}_{13} \mathrm{ClNO}_{5}$ Sb: Calcd. (\%): C 43.58, H 2.80, N 2.99, Sb 25.99; Found (\%): C 43.20, H 2.50, N 2.67, Sb 25.34. FAB-MS $(m / z) 467,469(\mathrm{M}+2)$. IR $v 3276(\mathrm{~N}-$ $\mathrm{H}), 1666(\mathrm{C}-\mathrm{N}), 1540\left(\mathrm{CO}_{2}\right)_{\mathrm{as}}, 1311\left(\mathrm{CO}_{2}\right)_{\mathrm{s}}, \Delta v\left(\mathrm{CO}_{2}\right)$ : 229, $425(\mathrm{~N} \rightarrow \mathrm{Sb}), 580(\mathrm{O}-\mathrm{Sb}) \mathrm{cm}^{-1}$. ${ }^{1} \mathrm{H}$ NMR (DMSO$\mathrm{d} 6,300 \mathrm{MHz})$ 8.24 (s, NH), 7.10-8.1 (m, Ar), $5.06(\mathrm{t}$, $\mathrm{CH}, \mathrm{J}: 9.7), 3.42\left(\mathrm{~d}, \mathrm{CH}_{2}, \mathrm{~J}\right.$ : 9.3). ${ }^{13} \mathrm{C}$ NMR (DMSO-d6, $75 \mathrm{MHz}) 180.6(\mathrm{CONH}), 174.0(\mathrm{COO}), 169.5$ (COO), 125-136 (Ar), $66.8(\mathrm{CH}), 30.6\left(\mathrm{CH}_{2}\right)$.

\section{Synthesis of VIII}

Yield: $58 \% . \mathrm{C}_{15} \mathrm{H}_{9} \mathrm{ClNO}_{5} \mathrm{Sb}$ : Calcd.(\%): C 40.90, H 2.06, N 3.18, Sb 27.64; Found (\%):C 40.71, H 1.89, N 2.91, Sb 27.22. FAB-MS $(m / z) 439,441(\mathrm{M}+2)$. IR $v 3266(\mathrm{~N}-$ $\mathrm{H}), 1678(\mathrm{C}-\mathrm{N}), 1541\left(\mathrm{CO}_{2}\right)_{\mathrm{as}}, 1336\left(\mathrm{CO}_{2}\right)_{\mathrm{s}}, \Delta v\left(\mathrm{CO}_{2}\right)$ : 137, $446(\mathrm{~N} \rightarrow \mathrm{Sb}), 568(\mathrm{O}-\mathrm{Sb}) \mathrm{cm}^{-1} .{ }^{1} \mathrm{H}$ NMR (DMSOd6, $300 \mathrm{MHz}) 8.16$ (s, NH), 7.06-8.55 (m, Ar). ${ }^{13} \mathrm{C}$ NMR (DMSO-d6, $75 \mathrm{MHz}) 183.2(\mathrm{CONH}), 170.4(\mathrm{COO})$, 172.8 (COO), 123-137 (Ar). 


\section{Anti-leishmanial activity}

Anti-leishmanial activity of the compound was carried out on the pre-established cultures of L. major (JISH118), L. major (MHOM/PK/88/DESTO), L. tropica (K27), L. infantum (LEM3437), L. mex mex (LV4) and L. donovani (H43). Parasites were cultured in medium M199 with 10\% foetal bovine serum; $25 \mathrm{mM}$ of HEPES, and $0.22 \mu \mathrm{g}$ of penicillin and streptomycin, respectively at $24^{\circ} \mathrm{C}$ in an incubator. $1 \mathrm{mg}$ of each test compound (I-VIII) was dissolved in $1 \mathrm{~mL}$ of water, ethanol, methanol and DMSO according to their solubilities. $1 \mathrm{mg}$ of Amphotercin B was also dissolved in 1 $\mathrm{mL}$ of DMSO as reference drug. Parasites at log phase were centrifuged at $3000 \mathrm{rpm}$ for $3 \mathrm{~min}$. Parasites were diluted in fresh culture medium to a final density of 2 $\times 10^{6}$ cells $/ \mathrm{mL}$. In 96 -well plates, $180 \mu \mathrm{L}$ of medium was added in different wells. $20 \mu \mathrm{L}$ of the extracts was added in medium and serially diluted. $100 \mu \mathrm{L}$ of parasite culture was added in all the wells. Four rows left for negative and positive controls: water, ethanol, methanol and DMSO, respectively, serially diluted in medium whereas positive control contained varying concentrations of standard antileishmanial compound, i.e. AmphotericinB. The plates were incubated for $72 \mathrm{~h}$ at $24^{\circ} \mathrm{C}$. Results were analyzed through dose versus response by using nonlinear regression curve fit with Graphad Prims5.

\section{Anti-fungal activity}

Agar tube dilution method was used for screening antifungal activities against Aspergillus Flavus, Aspergillus Fumigants, Aspergillus Niger, and Fusarium Solani. A sample of Media supplemented with DMSO and reference antifungal drugs was used as negative and positive control, respectively. Tubes were then incubated at $27^{\circ} \mathrm{C}$ for 4-7 days and examined twice weekly during incubation. Standard drug, Miconazole, used for the above stated fungi, growth in media containing sample under test were determined by linear growth $(\mathrm{mm})$ measuring, and percent inhibition of growth was calculated with reference to negative control using formula.

$$
\% \text { Inhibition }=100-\frac{\text { Linear growth in test }(\mathrm{mm})}{\text { Linear growth in control }(\mathrm{mm})} 100
$$

\section{Results and discussion}

Ligands 2-\{[(carboxymethyl)amino $]$ carbonyl\}benzoic acid (I), 2-\{[(2-carboxyethyl)amino]carbonyl\}benzoic acid (II), $2-\{[(1$-carboxy-2-phenylethyl)amino $]$ carbonyl $\}$ benzoic acid (III), and 2-[(4-carboxyanilino)carbonyl]benzoic acid (IV), and the complexes (V-VIII), all of which were synthesized using a general procedure as shown in Figure 1. Analytic data for the complexes confirmed the equimolar stoichiometries thereby tridentate ligation (ONO) of I-IV towards $\mathrm{Sb}^{\mathrm{III}}$ centre.

\section{FTIR spectra}

Solid-state FTIR spectra were recorded in the spectral range of 4000-400 $\mathrm{cm}^{-1}$, and important vibrational frequencies were observed in this range. In the spectra of ligands (I-IV), characteristic broad band of carboxylic $\mathrm{COOH}$ functionality was observed in the range of 2800$3000 \mathrm{~cm}^{-1}$; OC-NH bond vibrated at $2600 \mathrm{~cm}^{-1}$; and aromatic $\mathrm{C}=\mathrm{C}$ at $1500 \mathrm{~cm}^{-1}$ [16]. Broad band observed for carboxylic group disappeared in the spectra of complexes indicating deprotonation of ligand. In the spectra of compounds V-VIII, appearance of new band of medium intensity around $430 \mathrm{~cm}^{-1}$ indicated the coordination from $\mathrm{N}$ to antimony $(\mathrm{O}=\mathrm{C}-\mathrm{NH} \rightarrow \mathrm{Sb})$ in pseudotrigonal bipyramidal arrangement (Figure 1) [17]. All the other bonds appeared at the same positions as in the spectra of the ligands ruling out coordination from carbonyl of phthalimido groups (Figure 1).

\section{Solution-state multinuclear NMR spectra}

In the solution-state ${ }^{1} \mathrm{H}$ and ${ }^{13} \mathrm{C}$ NMR spectra of compounds (V-VIII), all the nuclei resonated at appropriate positions; in ${ }^{1} \mathrm{H}$ NMR spectra, the disappearance of carboxylic protons confirmed deprotonation as observed in the FTIR spectra of ligands (I-IV). In addition, downfield shift of imine proton proved the coordinate linkage of imine group toward antimony center $(-\mathrm{NH} \rightarrow \mathrm{Sb})$ [18]. Similarly, in ${ }^{13} \mathrm{C}$ NMR spectra, carbonyl $(\mathrm{C}=\mathrm{O})$ adjacent to imine group resonated at downfield position compared with that of the ligands confirming coordination linakge of imine with antimony center; all these facts proved the 1:1 ligand to metal stoichiometry in pseudotrigonal bipyramidal geometry (Figure 1) [19-21]. Further, either of the carboxylic groups displayed different chemical shifts with carboxylic group attached to phenyl ring appeared slightly at high filed.

\section{MS \& TGA analysis}

In the FAB MS spectra of complexes VI-VIII, base peak was observed at $245 \mathrm{~m} / z$ due to [ $\mathrm{O}=\mathrm{C}-\mathrm{O}-(\mathrm{SbCl})-\mathrm{O}$ $\mathrm{C}=\mathrm{O}]^{+}$fragment. Molecular ion peaks of very low intensity were observed with $\mathrm{M}+2$ peaks for isotopic ${ }^{123} \mathrm{Sb}$ were also seen. Based on the data obtained, fragmentation patterns for ligands I-IV (Figure 2a) and complexes V-VIII (Figure 2b) have been proposed [20]. During the TGA analyses, heating rates were suitably controlled at $10^{\circ} \mathrm{C} / \mathrm{min}$ under a nitrogen atmosphere, and the weight loss was measured ranging from ambient temperature up to $700^{\circ} \mathrm{C}$. The weight losses for all the complexes were calculated for the corresponding temperature ranges and are shown in Table 1 . The metal percentages left as metal oxide residues were compared with those 


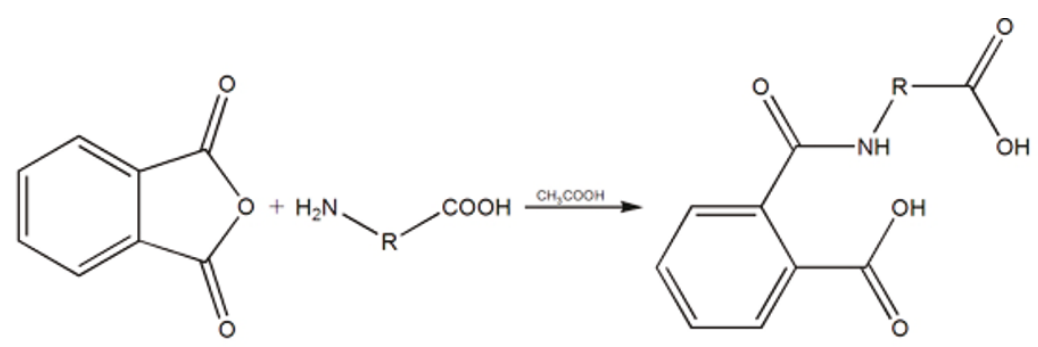

Where R: $\mathrm{CH}_{2}(\mathrm{I}), \mathrm{CH}_{2}-\mathrm{CH}_{2}$ (II), (CH) $\mathrm{CH}_{2}-\mathrm{C}_{6} \mathrm{H}_{5}(\mathrm{III}), \mathrm{C}_{6} \mathrm{H}_{4}(\mathrm{IV})$
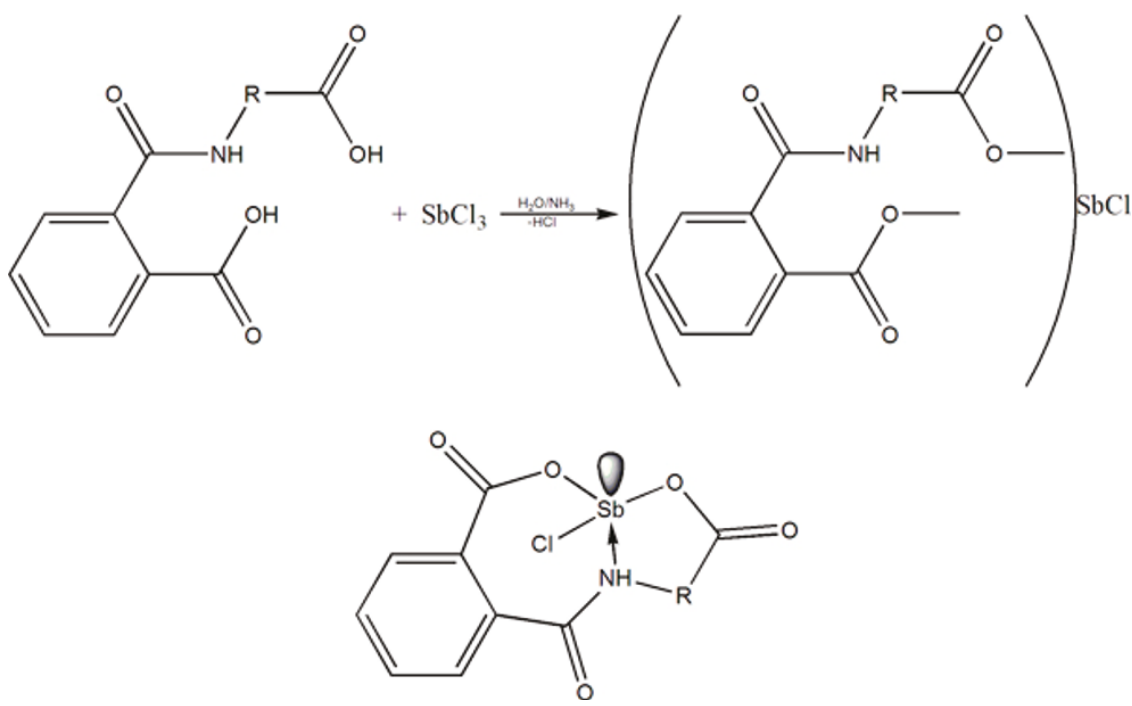

Figure 1 Synthesis (I-VIII) and pseudotrigonal bipyramidal geometry.

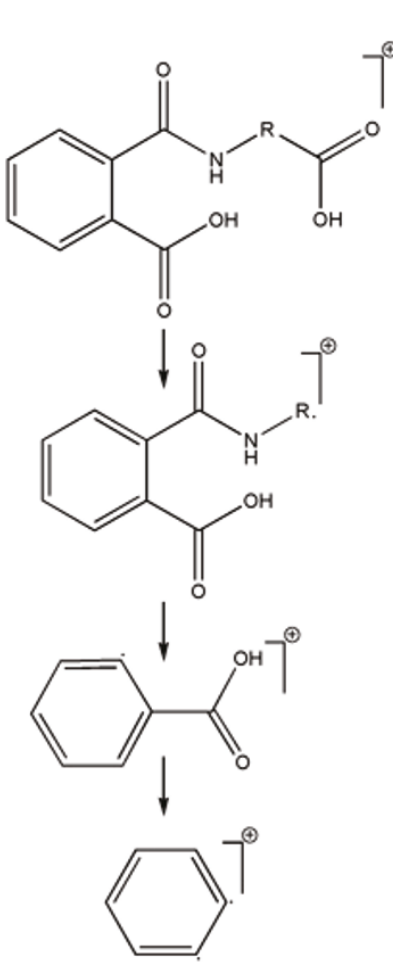

(a)

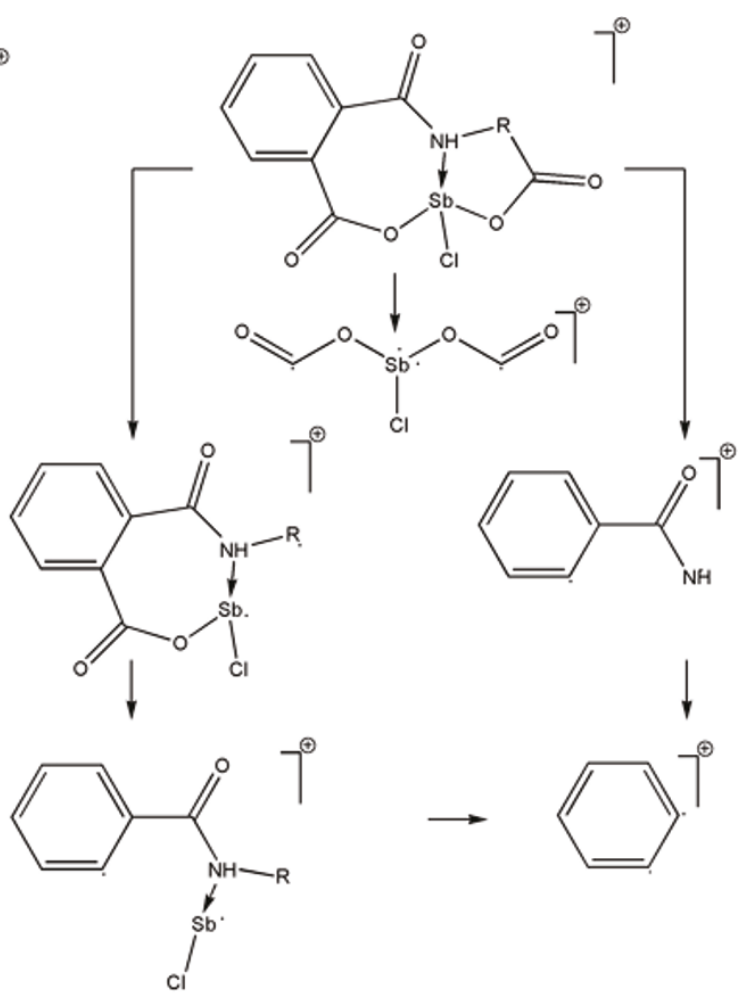

(b) 
Table 1 Thermal analysis data of complexes V-VIII

\begin{tabular}{|c|c|c|c|c|c|c|c|c|}
\hline \multirow[b]{2}{*}{ Formula } & \multicolumn{3}{|c|}{ Loss of $\mathrm{Cl}$} & \multicolumn{3}{|c|}{ Oxide formation } & \multicolumn{2}{|c|}{$\%$ Metal } \\
\hline & Temp. range $\left({ }^{\circ} \mathrm{C}\right)$ & Calculated & Found & Decomposition stage $\left({ }^{\circ} \mathrm{C}\right)$ & Temperature $\left({ }^{\circ} \mathrm{C}\right)$ & $\%$ Residue & Calculated & Found \\
\hline $\mathrm{C}_{10} \mathrm{H}_{7} \mathrm{ClNO}_{5} \mathrm{Sb}$ & $180-214$ & 9.6 & 9.3 & $296-530$ & 530 & 35 & 32.2 & 31.8 \\
\hline $\mathrm{C}_{11} \mathrm{H}_{9} \mathrm{ClNO}_{5} \mathrm{Sb}$ & $178-207$ & 9.2 & 8.8 & $300-485$ & 485 & 66 & 31.0 & 30.7 \\
\hline $\mathrm{C}_{17} \mathrm{H}_{13} \mathrm{ClNO}_{5} \mathrm{Sb}$ & $171-211$ & 8.4 & 8.2 & $280-500$ & 500 & 72 & 26.0 & 25.4 \\
\hline $\mathrm{C}_{15} \mathrm{H}_{9} \mathrm{ClNO}_{5} \mathrm{Sb}$ & $182-220$ & 8.9 & 8.5 & $308-550$ & 550 & 70 & 27.6 & 26.3 \\
\hline
\end{tabular}

Table 2 In vitro Anti-leishmanial effect $\left(\mathrm{IC}_{50}\right.$ in $\mu \mathrm{g} / \mathrm{mL}$ ) of I-VIII and standard drug (AmphotericinB)

\begin{tabular}{lccccccccc}
\hline Leishmanial strain & & \multicolumn{9}{c}{ Compound } & \multicolumn{1}{c}{} \\
& $\mathbf{I}$ & $\mathbf{~ I I}$ & III & IV & V & VI & VII & VIII & AmphotericinB \\
\hline L. major & 0.26 & 0.28 & 0.38 & 0.24 & 0.24 & 0.25 & 0.29 & 0.17 & 0.19 \\
L. major (Pak) & 0.33 & 0.32 & 0.30 & 0.31 & 0.24 & 0.33 & 0.22 & 0.11 & 0.22 \\
L. tropica & 0.22 & 0.39 & 0.25 & 0.23 & 0.24 & 0.35 & 0.28 & 0.18 & 0.25 \\
L. mex mex & 0.29 & 0.32 & 0.27 & 0.40 & 0.24 & 0.31 & 0.28 & 0.13 & 0.18 \\
L. donovani & 0.39 & 0.31 & 0.32 & 0.20 & 0.24 & 0.29 & 0.33 & 0.10 & 0.20 \\
\hline
\end{tabular}

Table 3 In vitro Anti-fungal Effect of I-VIII and Standard Drug (Miconazole)

\begin{tabular}{|c|c|c|c|c|c|c|c|c|c|}
\hline \multirow[t]{2}{*}{ Fungi } & \multicolumn{9}{|c|}{ Compound } \\
\hline & 1 & II & III & IV & v & VI & VII & VIII & Miconazole \\
\hline $\begin{array}{l}\text { Aspergillus } \\
\text { flavus }\end{array}$ & + & ++ & ++ & ++ & + & ++ & ++ & ++++ & +++ \\
\hline $\begin{array}{l}\text { Aspergillus } \\
\text { Fumigants }\end{array}$ & ++ & ++ & + & +++ & ++ & ++ & +++ & ++++ & +++ \\
\hline $\begin{array}{l}\text { Aspergillus } \\
\text { Niger }\end{array}$ & ++ & + & + & ++ & ++ & + & +++ & ++++ & ++++ \\
\hline $\begin{array}{l}\text { Fusarium } \\
\text { Solani }\end{array}$ & +++ & ++ & ++ & + & ++ & +++ & ++ & ++++ & +++ \\
\hline
\end{tabular}

Key: +: No activity, ++: Low activity, +++: moderate activity, ++++: significant activity

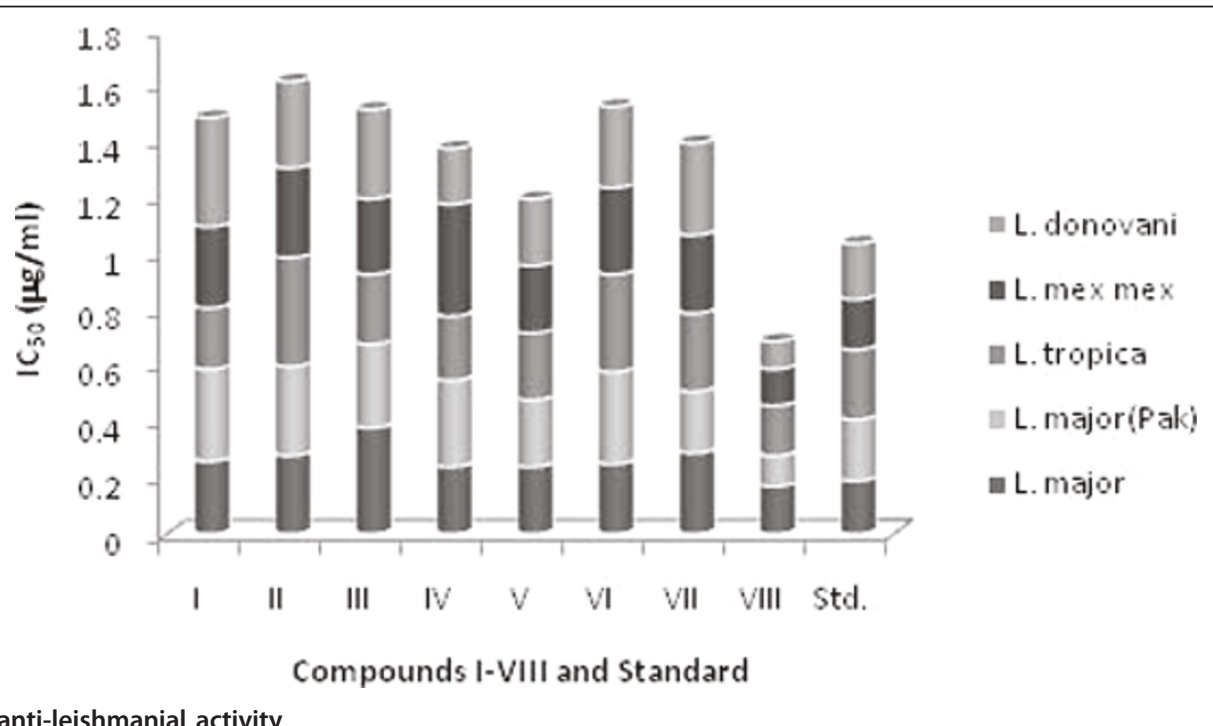

Figure 3 In vitro anti-leishmanial activity 
determined by analytic metal content determination. Complexes V-VIII exhibited a three-stage decomposition pattern; as a first step, beginning of the weight loss occurred at 180,178,171, and $182 \mathrm{C}$, respectively, because of the escape of one $\mathrm{C} 1$ atom; next step of decomposition started at $280^{\circ} \mathrm{C}$ and extended up to $545^{\circ}$ $\mathrm{C}$ corresponding to the loss of rest of the ligand's components and formation of metal oxide [22].

All attempts employing different sets of conditions to obtain single crystals of the synthesized complexes suitable for XRD failed.

\section{Anti-leishmanial and anti-fungal activities}

All the compounds I-VIII were tested in vitro for their bioavailabilities against five leishmanial strains, i.e., $L$. major (JISH118), L. major (MHOM/PK/88/DESTO), $L$. tropica (K27), L. infantum (LEM3437), L. mex mex (LV4), and L. donovani (H43); and four fungi, viz., Aspergillus Flavus, Aspergillus Fumigants, Aspergillus Niger, and Fusarium Solani with one reference drug Amphotericin B, and the results are given in Tables 2 and 3 , respectively. In general all the complexes ( $\mathbf{V}$ VIII) showed weaker activity compared to ligands (I-IV) and the reference drugs, but the complex VIII showed significant activity comparable to reference drugs. The activities $\left(\mathrm{IC}_{50}\right)$ of all the compounds I-VIII together with AmphotericinB have been pictorially presented in Figure 3, and it is evident from the plot that the compound VIII exhibited significant activity. In complex VIII, the presence of bulkier R group, i.e., one benzyl moiety may be responsible for enhancement in drug uptake, thereby resulting significant activity $[23,24]$.

\section{Conclusions}

Antimony ${ }^{\mathrm{III}}$ center in all the synthesized complexes is pseudotrigonal bipyramidal. Complex containing benzyl group displays noteworthy anti-leishmanial and anti-fungal effects. Proper understanding of exact relationship between structure and activity needs further research.

\begin{abstract}
Author details
'Department of Chemistry, Kohat University of Science \& Technology, Kohat 26000, Khyber Pakhtunkhwa, Pakistan ${ }^{2}$ Department of Chemistry, The Islamia University of Bahawalpur, Bahawlpur, Punjab, Pakistan ${ }^{3}$ Faculty of Biological Sciences, Quaid-i-Azam University, Islamabad, Pakistan ${ }^{4}$ Institute of Pharmaceutical Sciences, Kohat University of Science and Technology, Kohat 26000, Khyber Pakhtunkhwa, Pakistan ${ }^{5}$ Department of Chemistry, Gomal University, Dera Ismail Khan, Khyber Pakhtunkhwa, Pakistan
\end{abstract}

\section{Competing interests}

The authors declare that they have no competing interests.

Received: 9 April 2011 Accepted: 18 July 2011 Published: 18 July 2011
References

1. Castro JR, Mahon MF, Molloy KC (2006) Aerosol-assisted CVD of antimony sulfide from antimony dithiocarbamates. Chem Vapor Depos 12:601-607

2. Chung JS (1990) Acid-base and catalytic properties of metal compounds in the preparation of polyethylene terephthalate). J Macromol Sci A 27:479-490

3. Biros SM, Bridgewater BM, Estrada AV, Tanski JM, Parkin G Antimony ethylene glycolate and catecholate compounds: structural characterization of polyesterification catalysts. Inorg Chem41:4051-4057

4. Tanski JM, Kelly BV, Parkin G (2005) Multidentate aryloxide and oxoaryloxide complexes of antimony: synthesis and structural characterization of $\left[\eta^{4}-\mathrm{N}\left(\mathrm{O}-\mathrm{C}_{6} \mathrm{H}_{4} \mathrm{O}\right)_{3}\right] \mathrm{Sb}\left(\mathrm{OSM} \mathrm{N}_{2}\right),\left\{\left\{\left[\eta^{3}-\mathrm{N}\left(\mathrm{O}-\mathrm{C}_{6} \mathrm{H}_{4} \mathrm{OH}\right)\left(\mathrm{O}-\mathrm{C}_{6} \mathrm{H}_{4} \mathrm{O}\right)_{2}\right] \mathrm{Sb}\right\}_{2}\left(\mu_{2}-\mathrm{O}\right)\right\}_{2}$ and $\left\{\left[\eta^{3}-\mathrm{PhN}\left(\mathrm{o}-\mathrm{C}_{6} \mathrm{H}_{4} \mathrm{O}\right)_{2}\right] \mathrm{Sb}_{4}\left(\mu_{3}-\mathrm{O}\right)_{2}\right.$. Dalton Trans 2442-2447

5. Kovaleva EV, Zemnukhova LA, Nikitin VM, Koryakova MD, Speshneva NV (2002) Biological properties of Antimony(III) fluoride complexes. Russ J Appl Chem 75:954-958

6. Dostál L, Jambor R, Ruzika A, Jirasko R, Cisarova I, Holecek J (2008) The synthesis of organoantimony(III) difluorides containing $Y, C, Y$ pincer type ligands using organotin(IV) fluorinating agents. J Fluor Chem 129:167-172

7. Gebel T (1997) Arsenic and antimony: comparative approach on mechanistic toxicology. Chem Biol Interact 107:131-144

8. Cantos G, Barbieri CL, lacomini M, Gorin PAJ, Travassos LR (1993) Synthesis of antimony complexes of yeast mannan and mannan derivatives and their effect on Leishmania-infected macrophages. Biochem J 289:155-160

9. Sharutin W, Sharutina OK, Pakusina AP, Platonova TP, Fukin GK, Zakharov LN (2001) Synthesis and structure of triphenylantimony dipropionate. Russ J Coord Chem 27:368-370

10. Barucki H, Coles SJ, Costello JF, Gelbrich T, Hursthouse MB (2000) Characterising secondary bonding interactions within triaryl organoantimony $(V)$ and organobismuth $(V)$ complexes. J Chem Soc Dalton Trans 2319-2325

11. Sharutin W, Sharutina OK, Bonsae EA, Pakusina AP, Gatilov YuV, Adonin NYu, Starichenko VF (2000) Tetra- and triarylantimony fluorobenzoates: synthesis and structures. Russ J Coord Chem 28:333-340

12. Kasuga NC, Onodera K, Nakano S, Hayashi K, Nomiya K (2006) Syntheses, crystal structures and antimicrobial activities of 6-coordinate antimony(III) complexes with tridentate 2-acetylpyridine thiosemicarbazone, bis (thiosemicarbazone) and semicarbazone ligands. J Inorg Biochem 100:1176-1186

13. Sharutin W, Sharutina OK, Panova LP, Platonova TP, Pakusina AP, Bel'kii VK (2002) Synthesis and structure of tri-p-tolylantimony ditosylate. Russ J Gen Chem 72:229-231

14. Perrin DD, Armengo ELF (1988) Purification of laboratory chemicals. Pergamon, Oxford, UK

15. Mendham J, Denney RC, Barnes JD, Thomas M, (eds) (2003) Vogel's text book of quantitative chemical analysis. Pearson Education Pvt. Ltd., Singapore

16. Dianzhong F, Bo W (1993) Complexes of cobalt(II), nickel(II), copper(II), zinc (II) and manganese(II) with tridentate Schiff base ligand. Trans Met Chem 18:101-103

17. Chunyan G, Xiaofang M, Jinlei T, Dongdong L, Shiping $Y(2010)$ Synthesis, structure, and DNA binding of three reduced aminoacid Schiff-base zinc(II), nickel(II), and cadmium(II) complexes. J Coord Chem 63:115-123

18. Machuč L, Dostál L, Jambor R, Handliř K, Jirásko R, Růžička A, Císařová I, Holeček J (2007) Intramolecularly coordinated organoantimony(III) carboxylates. J Organomet Chem 692:3969-3975

19. Liu Y, Tiekink ERT (2005) Supramolecular associations in binary antimony(III) dithiocarbamates: influence of ligand steric bulk, influence on coordination geometry, and competition with hydrogen-bonding. Cryst Eng Commun 7:20-27

20. Li JS, Ma YQ, Cui JR, Wang RQ (2001) Synthesis and in vitro antitumor activity of some tetraphenylantimony derivatives of exo-7-oxa-bicyclo[2,2,1] heptane (ene)-3-arylamide-2-acid. Appl Organomet Chem 15:639-645

21. Mahajan K, Swami M, Singh RV (2009) Microwave synthesis, spectral studies, antimicrobial approach, and coordination behavior of antimony(III) and bismuth(III) compounds with benzothiazoline. Russ J Coord Chem 35:179-185

22. Stefan SL (1994) Thermal decomposition of some metal chelates of substituted hydrazopyrazolones. J Therm Anal 42:1299-1312 
23. Croft SL, Sundar S, Fairlamb AH (2006) Drug resistance in leishmaniasis. Clin Microbiol Rev 19:111-126

24. Kuryshev YA, Wang Lu, Wible BA, Wan X, Ficker E (2006) Antimony-based antileishmanial compounds prolong the cardiac action potential by an increase in cardiac calcium currents. Mol Pharmacol 69:1216-1225

doi:10.1186/2191-2858-1-2

Cite this article as: Khan et al.: In vitro anti-leishmanial and anti-fungal effects of new Sb"II carboxylates. Organic and Medicinal Chemistry Letters 2011, 1:2.

\section{Submit your manuscript to a SpringerOpen ${ }^{\circ}$ journal and benefit from:}

- Convenient online submission

- Rigorous peer review

- Immediate publication on acceptance

- Open access: articles freely available online

- High visibility within the field

- Retaining the copyright to your article

Submit your next manuscript at $\gg$ springeropen.com 